\title{
Nitzschia pseudodelicatissima - a source of domoic acid in the Bay of Fundy, eastern Canada
}

\author{
Jennifer L. Martin, K. Haya, L. E. Burridge, D. J. Wildish \\ Department of Fisheries and Oceans, Biological Station, St. Andrews, New Brunswick, Canada E0G 2X0
}

\begin{abstract}
Circumstantial evidence is presented that domoic acid detected in softshell clams Mya arenaria and blue mussels Mytilus edulis from the southwestern Bay of Fundy, eastern Canada, during July to October 1988 was obtained by feeding on the pennate diatom Nitzschia pseudodelicatissima. This microalga was the most abundant organism observed in weekly samples collected at the surface, $10 \mathrm{~m}$ depth and bottom from nearly all of the 18 locations sampled during the same period. Phytoplankton net hauls consisting principally of $N$. pseudodelicatissima contained levels of domoic acid up to 3.5 $\mu \mathrm{g} \mathrm{g}^{-1}$ Isolates of 9 dominant phytoplankton species occurring in the southwestern Bay of Fundy during July to October 1988 were cultured and tested for the presence of domoic acid; only $N$. pseudodelicatissima cultures produced the toxin at concentrations of $7.0 \times 10^{-15}$ to $9.8 \times 10^{-14} \mathrm{~g} \mathrm{cell}^{-1}$ Since cultures of $N$. pseudodelicatissima were not axenic, the possibility exists that either an intra or extracellular microorganism is acting independently, or in association with the diatom, to produce domoic acid.
\end{abstract}

\section{INTRODUCTION}

During late fall of 1987, an episode of food poisoning later described as amnesic shellfish poisoning (ASP) occurred in Canada that resulted in more than 100 illnesses and 3 deaths (Todd 1990). The source of the poisoning was determined to be from cultured blue mussels Mytilus edulis harvested from aquaculture operations in eastern Prince Edward Island (PEI), Canada. Toxins from microalgae were accumulated while filter feeding and stored in their tissues. The toxin in the mussels was identified as domoic acid (Wright et al. 1989) and the major source was found to be associated with Nitzschia pungens forma multiseries (Subba Rao 1988, Bates et al. 1989).

Human symptoms of ASP include gastric (within $24 \mathrm{~h}$ ) and neurological signs such as dizziness, disorientation and memory loss (within $48 \mathrm{~h}$ ). Several months later, some of those over $40 \mathrm{yr}$ old that had been affected still showed neurological symptoms and shortterm memory loss (Todd 1990).

Although most species of microalgae are harmless, a few can produce toxins that cause harm, and even death, to vertebrate consumers. Prior to 1988 , the organism of major concern to the shellfish industry in the Bay of Fundy was Alexandrium fundyense", the

\footnotetext{
- Formerly referred to as Gonyaulax excavata
}

organism responsible for paralytic shellfish poisoning (PSP) on Canada's Atlantic coast. A. fundyense blooms annually in the Bay of Fundy (Martin \& White 1988). Shellfish accumulate the toxins while filter feeding and the toxins are stored in their tissues. Many shellfish areas in the Bay of Fundy are closed to harvesting annually during periods when shellfish contain unacceptable levels of PSP toxins. As a result of the ASP outbreak in PEI during November 1987, shellfish from other coastal regions in Canada were monitored for domoic acid in 1988/89. Results from this monitoring showed that extracts of blue mussels and soft-shell clams Mya arenaria from some areas in southwestern Bay of Fundy also contained domoic acid (Gilgan et al. 1990, Haya et al. unpubl.).

This paper presents evidence that production of domoic acid in the southwestern Bay of Fundy in 1988 was associated with a species of pennate diatom, Nitzschia pseudodelicatissima, not previously reported as a source of toxin production.

\section{MATERIALS AND METHODS}

Samples were collected from the surface, $10 \mathrm{~m}$ depth and $1 \mathrm{~m}$ above bottom at 18 locations off the New Brunswick coast in the southwest Bay of Fundy (Fig. 1) Temperature, salinity and dissolved oxygen were meas- 


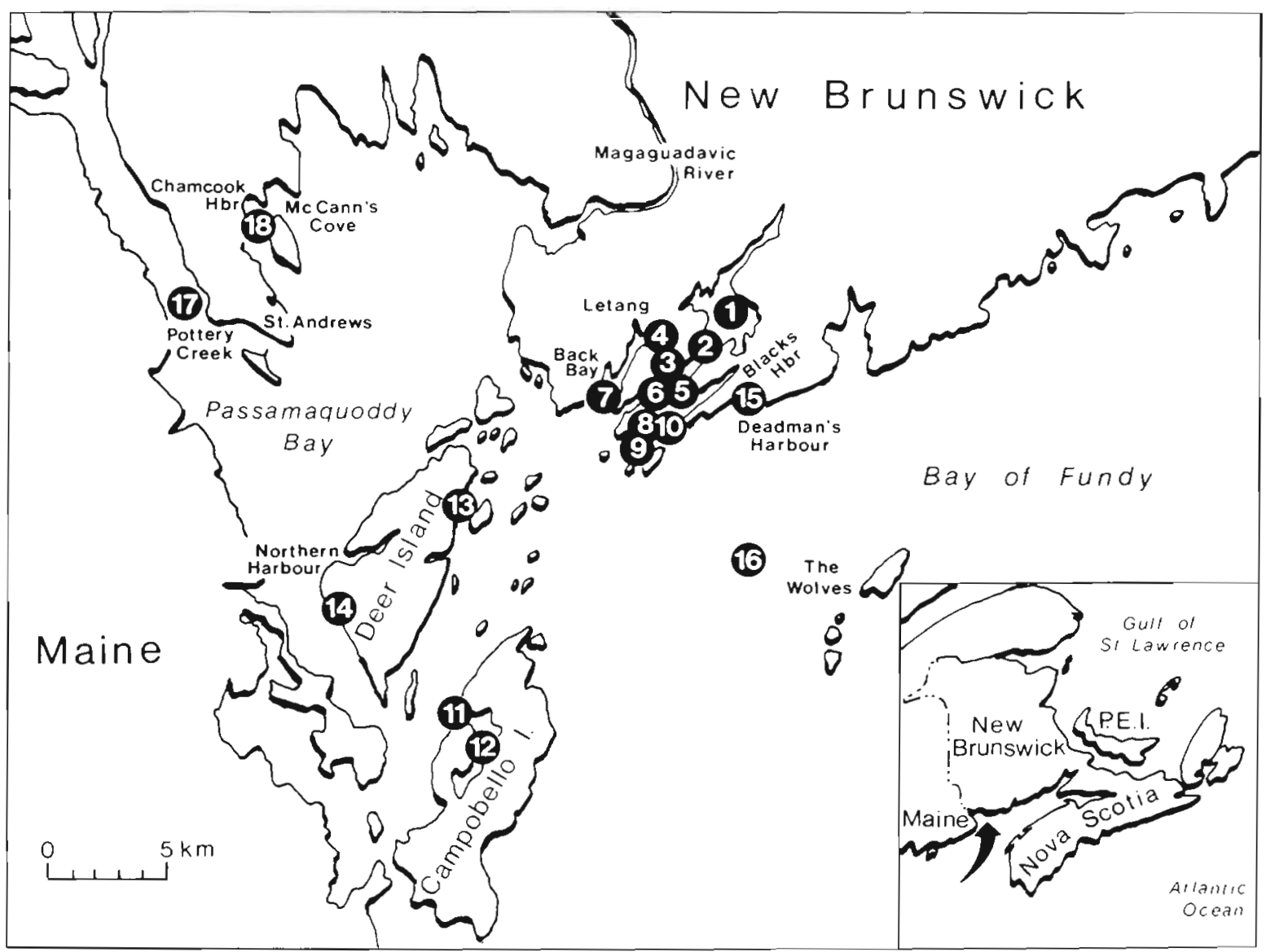

Fig. 1. Sampling locations in the southwestern Bay of Fundy, Canada

ured as described previously (Wildish et al. 1990) and phytoplankton species were identified. Samples were taken weekly from June 1 to October 25, 1988 , between 09:00 and 16:00 $\mathrm{h}$, irrespective of the tidal stage. Surface water was collected by bucket; additional samples were collected at $10 \mathrm{~m}$ depth and $1 \mathrm{~m}$ above bottom by a $1.8 \mathrm{I}$ Niskin bottle equipped with a reversing thermometer.

Phytoplankton samples were immediately preserved in $2.5 \%$ formalin:acetic acid $(1: 1)$ or $2.0 \%$ Lugol's lodine and later $50 \mathrm{ml}$ subsamples were counted with an inverted microscope. All organisms $>5 \mu \mathrm{m}$ were identified; they included diatoms, dinoflagellates, ciliates and smaller zooplankton.

Phytoplankton were identified as described in Wildish et al. $(1988,1990)$. Identification of the most abundant organism, Nitzschia pseudodelicatessima Hasle, was confirmed by $M$. Poulin (National Museums of Canada, Ottawa, Ontario, Canada) and G. R. Hasle (University of Oslo, Norway). Cells were 55 to $80 \mu \mathrm{m}$ in length and 1.5 to $2.0 \mu \mathrm{m}$ in width, symmetrical and tapered toward the outer ends (Fig. 2). Cells were united in chains of 8 to 10 cells by overlapping of the ends.
Plankton for toxin analysis was collected during the main part of the bloom at Pottery Creek, Chamcook Harbour and The Wolves (Fig. 1) with a $20 \mu \mathrm{m}$ Nitex mesh net that was $50 \mathrm{~cm}$ in diameter and towed near the surface at a speed of less than 1 knot for $10 \mathrm{~min}$. Contents were kept on ice for 1 to $2 \mathrm{~h}$ during the return trip to the laboratory. A subsample was removed for microscopic examination to identify tow contents. The seawater was removed by aspiration and centrifugation at $750 \times g$ for $15 \mathrm{~min}$. The phytoplankton was weighed, then resuspended in a minimum amount of distilled water. The slurry was sonicated with a Sonifer ${ }^{T M}$ cell disruptor (Branson) until microscopic examination indicated $>90 \%$ of cells were ruptured. The supernatant was passed through a Centrifree ${ }^{T M} 10$ micropartition system (30000 MW cut-off; Amicon) by centrifugation at $2500 \times \mathrm{g}$ for $60 \mathrm{~min}$.

Domoic acid concentrations were determined by the HPLC method of Lawrence et al. (1989) with the following conditions: Whatman Partisil II ODS-10 $250 \times 4.6$ mm C18 column; Altex Model 110B pump delivering $12.5 \%$ acetonitrile in distilled water $(\mathrm{pH}$ adjusted to 3 with $\mathrm{H}_{3} \mathrm{PO}_{4}$ ) at $1 \mathrm{ml} \mathrm{min}{ }^{-1} ; 20 \mu$ Altex injection loop; UV detection using a Schoeffel SF 770 variable 
wavelength detector set at $242 \mathrm{~nm}$. The UV detector response was captured by an Apple Ile computer running Chromatochart ${ }^{\mathrm{TM}}$ (Interactive Microware Inc.) The calibration curve $\left(20 \mu \mathrm{l}\right.$ injection, $\left.0.4-5.5 \mu \mathrm{g} \mathrm{ml^{-1 }}\right)$ was prepared with domoic acid (Diagnostic Chemicals Charlottetown, PEI), standardized with an instrument calibration solution, DACS-1 $\left(89 \mu \mathrm{g} \mathrm{m}^{-1}\right.$; National Research Council of Canada, Halifax, NS). Identification of domoic acid was also confirmed by FMOC derivitization and HPLC analysis (R. Pocklington, Dartmouth, NS).

Algal species observed in plankton samples containing domoic acid were isolated into culture. Single cells were taken with a capillary pipet, washed 2 to 3 times and grown in culture tubes initially using $\mathrm{f} / 8-\mathrm{Si}$ and later $\mathrm{f} / 2$ (Guillard 1984) at 12 to $14^{\circ} \mathrm{C}$, with an irradiance level of $45 \mu \mathrm{E} \mathrm{m} \mathrm{m}^{-2} \mathrm{~s}^{-1}$ from cool-white fluorescent bulbs and a $14: 10 \mathrm{~h}$ light:dark cycle. There was no domoic acid detected in the sterile medium used for growth.

\section{RESULTS}

During late July 1988, low levels of domoic acid were detected in soft-shell clams Mya arenaria and blue mussels Mytilus edulis from the following shellfish areas in Passamaquoddy Bay - Chamcook Harbour, Magaguadavic River, Pottery Creek, Brandy Cove, near St. Andrews and western Deer Island, Canada (Fig. 1) (Gilgan et al. 1990, Haya et al. unpubl.). Domoic acid levels increased slowly and, during late Augustearly September, reached levels above $20 \mu \mathrm{g}$ domoic acid $\mathrm{g}$ ' of whole tissue, necessitating the closure of such areas to harvesting. Most of these areas remained closed to harvesting until early October.

Analysis of phytoplankton from the southwestern Bay of Fundy region showed that for most of the 18 stations sampled, the pennate diatom Nitzschia pseudodelicatissima (Fig. 2) was the predominant organism observed between July 28 and September 27. Cell numbers of $N$. pseudodelicatissima for 1988 are shown in Table 1. During late July, $N$. pseudodelicatissima represented 60 to $90 \%$ of the total density for all species of phytoplankton identified. In early August to mid-September, it was 75 to $99 \%$ of the total; during late September, $99 \%$. The phytoplankton from all locations sampled tended to follow this pattern except at Deadman's Harbour (Stn 15) where concentrations of N. pseudodelicatissima remained considerably lower throughout sampling. At Chamcook Harbour (Stn 18) during 1988, the highest concentration of cells of $N$.

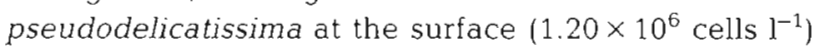
was observed on September 23. Domoic acid levels in

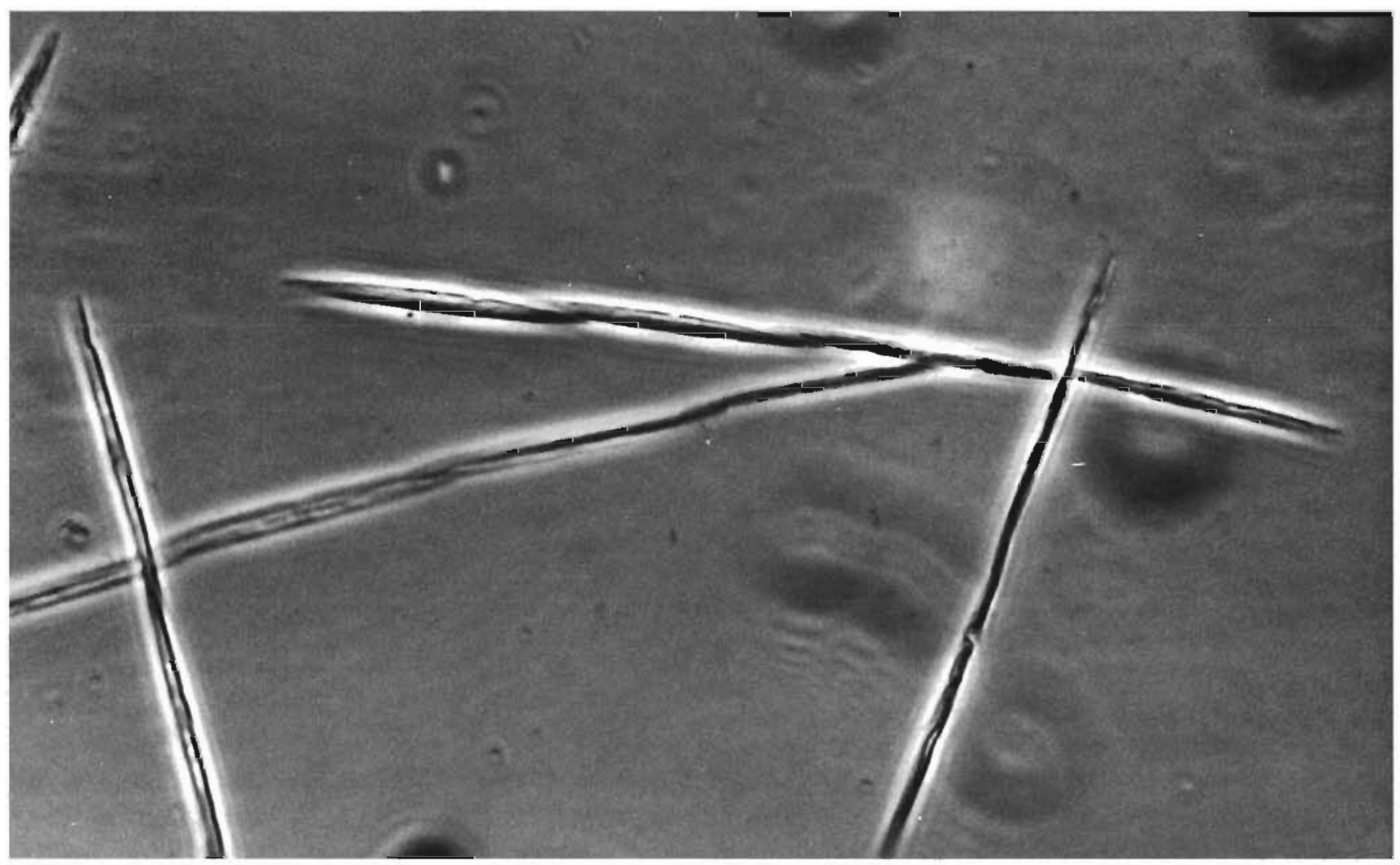

Fig. 2. Nitzschia pseudodelicatissima. Chains from culture, $\times 500$ 
Table 1. Nitzschia pseudodelicatissima. Density as number of cells $1^{-1}$ observed in surface samples during 1988

\begin{tabular}{|rrrrrrrrrrrrr}
\hline Stn & Jul 12 & Jul 19 & Jul 28 & Aug 2 & Aug 9 & Aug 16 & Aug 30 & Sep 6 & Sep 13 & Sep 21 & Sep 27 & Oct 4 \\
\hline 1 & 20 & 20 & 20 & 1260 & 100 & 920 & 2820 & 720 & 31520 & 1560 & 31000 & 20 \\
2 & 0 & 0 & 100 & & 860 & 2800 & 14240 & 720 & 48960 & 3100 & 110980 & 40 \\
3 & 0 & 20 & 40 & 6840 & 1060 & 23860 & 7100 & 7760 & 89760 & 15760 & 57120 & 180 \\
4 & 60 & 20 & 40 & & 2340 & 26120 & 5200 & 15600 & 32640 & 16680 & 66920 & 60 \\
5 & 0 & 0 & 300 & 4540 & 1080 & 29120 & 55480 & 2080 & 62200 & 14000 & 78340 & 80 \\
6 & 0 & 20 & 60 & 2680 & 6620 & 13320 & 2520 & 1240 & 44060 & 15380 & 35900 & 80 \\
7 & 0 & 80 & 2020 & 18200 & 2960 & 6620 & 93020 & 52220 & 551620 & 173800 & 138720 & 80 \\
8 & 80 & 240 & 40 & 23760 & 0 & 6720 & 19400 & 4300 & 88120 & 39200 & 159940 & 20 \\
9 & 0 & 140 & 360 & 16060 & 8960 & 9940 & 122400 & 14480 & 150140 & 27120 & 280700 & 0 \\
10 & 20 & 60 & 160 & 620160 & 2480 & 50600 & 54520 & 13380 & 197480 & 23100 & 143620 & 120 \\
11 & 0 & 11940 & 6400 & & 2140 & 9540 & 5960 & 60380 & & 48560 & 22840 & 40 \\
12 & 60 & 1900 & & & 720 & 3840 & 35900 & 47320 & & 62020 & 21200 & 0 \\
13 & & 9780 & 13700 & & 12340 & 60380 & 88120 & 127300 & & 202360 & 78340 & 0 \\
14 & 0 & 32240 & 81800 & 29540 & 11720 & 5580 & 76700 & 380260 & & 105640 & 39160 & 180 \\
15 & 0 & 80 & 0 & & 1020 & 5420 & 660 & 20 & 14800 & 6800 & 2860 & 200 \\
16 & 40 & 6160 & 5080 & 1060 & 14180 & 32640 & 23060 & 564680 & 406360 & 127300 & 173000 & 1300 \\
17 & 60 & 45700 & 91400 & 57120 & 31000 & 27740 & 75080 & 158300 & 66920 & 355780 & 76700 & 1340 \\
18 & & & & & & & & & 111100 & 1201160 & 380620 & 57120 \\
\hline
\end{tabular}

Table 2. Plankton tows collected from the southwestern Bay of Fundy and analyzed for domoic acid

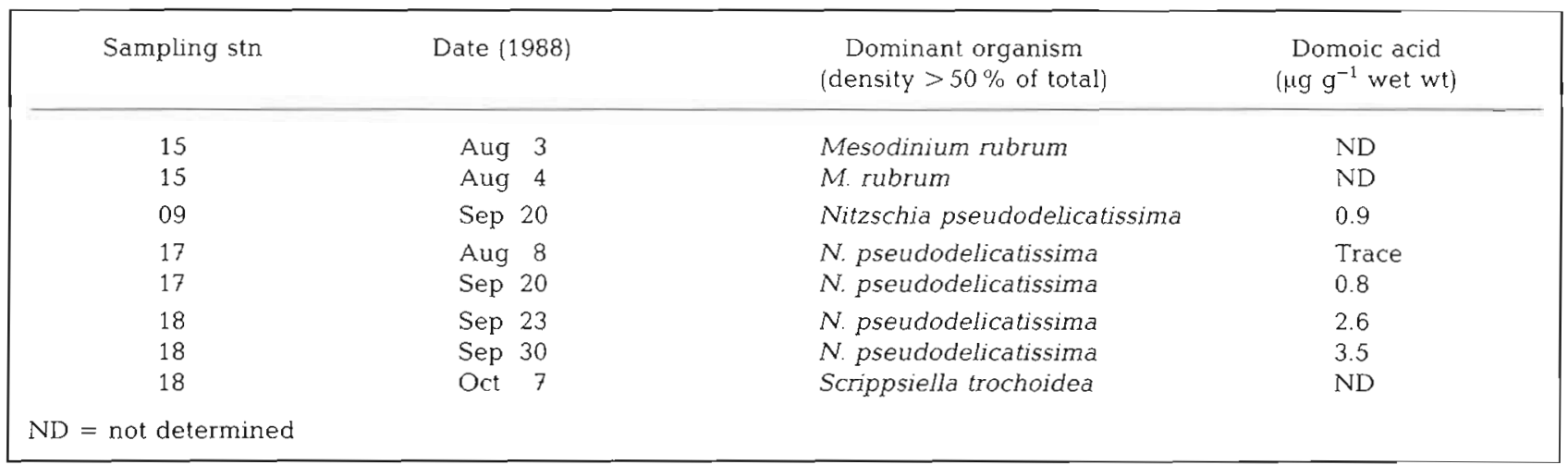

blue mussels reached the highest levels detected for the region $\left(74 \mu \mathrm{g} \mathrm{g}^{-1}\right.$ ) at Chamcook Harbour on September 22 (Gilgan et al. 1990).

When domoic acid was detected in shellfish and plankton tows, cells of organisms found in the water were isolated and cultured. The organisms cultured were the following diatoms: Chaetoceros simplex, Nitzschia closterium, N. pseudodelicatissima, $N$. pungens, Pleurosigma strigosum, Rhizosolenia alata, $R$. delicatula and a small, unidentified pennate diatom. The dinoflagellate Scrippsiella trochoidea and bacteria from the seawater were also cultured. Only cultures containing $N$. pseudodelicatissima produced domoic acid in the laboratory. $N$. pseudodelicatissima cells from cultures were extracted between 30 and $75 \mathrm{~d}$ after initial inoculations and yielded from $7.0 \times 10^{-15}$ to $9.8 \times 10^{-14} \mathrm{~g}$ domoic acid cell ${ }^{-1}$ Total numbers of cultured cells harvested varied from $3.7 \times 10^{5}$ to $7.5 \times 10^{7}$ cells total.

From plankton tow samples which were chemically analyzed (Table 2), detectable levels of domoic acid were found only in those where Nitzschia pseudodelicatissima was the dominant species observed. When other species dominated the plankton and $N$. pseudodelicatissima was either undetectable or present in low numbers, no domoic acid was detected.

\section{DISCUSSION}

Our results provide strong evidence that Nitzschia pseudodelicatissima played an important role in the production of domoic acid in the southwestern Bay of Fundy during 1988. It was the dominant species observed in the phytoplankton for the 2 mo period from July 28 to September 27 and, at times, made up more than $99 \%$ of the species observed for some areas. It therefore provided a major food source to shellfish in many shellfish-producing beds in the southwestern Bay of Fundy waters for an extended period of time. 
Microscopic examination of gut contents from soft-shell clams and blue mussels from affected areas revealed the presence of $N$. pseudodelicatissima frustules. Once ingested, the cells may have released domoic acid which was subsequently stored in bivalve tissues in a manner similar to the accumulation of paralytic shellfish toxins.

Our sampling of Nitzschia pseudodelicatissima populations during 1988 indicated that the cells were dispersed throughout the water column (Wildish et al 1990) with high concentrations observed at all depths. making the organism available for feeding on a continuous basis. This is consistent with physical oceanographic work reported by Trites \& Garrett (1983), indicating that within the Passamaquoddy region there is vigorous tidal mixing, resulting in weak stratification. Daborn (1986) suggested that this intense vertical mixing can also influence the whole of the shallow estuarine water column resulting in high primary productivity from nutrient recirculation. Nutrients were not analyzed at our sampling locations during 1988. However, experiments conducted in the laboratory indicate that the nutrient supply must have been maintained in ideal proportions and at sufficient levels in order to promote the growth of N.pseudodelicatissima as well as to enable it to flourish in the water column for such an extended period of time. Our phytoplankton surveys from other years indicate that the phytoplankton behaved differently in 1988. During 1987 and 1989. the $N$. pseudodelicatissima bloom lasted for a much shorter period and at lower densities (Wildish et al. $1988,1990)$. Although the benthic and zooplanktonic (or other potential grazer) populations were not measured during 1988, they may have been poorer than in most years. This may be a possible explanation for $N$. pseudodelicatissima blooming so densely that millions of cells were observed in southwestern Bay of Fundy waters. There may also have been an increased nutrient supply during the summer of 1988 so that a bloom was stimulated.

Nitzschia pseudodelicatissima has been present in the Bay of Fundy for a considerable time. Monthly records collected by Gran \& Braarud (1934) indicate that it bloomed regularly from March to September in the 1930's, with the highest concentration observed in $1931\left(1.0 \times 10^{3}\right.$ cells $\left.1^{-1}\right)$. However, they caution that since they used the centrifugation (instead of sedimentation) method for phytoplankton analysis, it may yield only $10 \%$ of the actual numbers of minute forms such as Nitzschia sp. N. pseudodelicatissima has been observed annually since 1976 from our samplings in the area, although little attention was given to it due to the lack of knowledge that it was associated with a human toxin in the Bay of Fundy. It also appears that this organism is cosmopolitan in its existence and not con- fined to Bay of Fundy waters (Hasle 1965). The question, therefore, arises as to whether domoic acid is associated with $N$. pseudodelicatissima in waters other than the Bay of Fundy or whether conditions and the strain are unique to this particular part of the world.

It must be emphasized that the Nitzschia pseudodelicatissima cultures used for detection of domoic acid in the lab were unialgal, but not axenic. The possibility exists, therefore, that either an intracellular or extracellular microorganism may be responsible for domoic acid production or that a symbiotic relationship may be required with the algal cells in order to produce domoic acid. Further studies are required in order to establish an axenic culture of $N$. pseudodelicatissima

One of the organisms isolated from eastern PEI during 1988 that has been shown to produce domoic acid in culture is Amphora coffaeiformis Ag. (Maranda et al. 1990). Another organism thought to be the major source of domoic acid in eastern PEI during the 1987 toxic mussel problem was a different species of Nitzschia - N. pungens forma multiseries (Subba Rao 1988, Bates et al. 1989). Another form of $N$. pungens is also found in Passamaquoddy Bay waters. However, when this organism was observed during our studies, it did not bloom very densely and generally made up $<1 \%$ of the total phytoplankton population at any particular sampling time. During 1988, a $N$. pungens isolate from Stn 17 was cultured and analyzed for domoic acid. No domoic acid was detected in the culture (detection limit $=0.2 \mu \mathrm{g} \mathrm{ml}^{-1}$ ) .

The production rate of domoic acid by Nitzschia pungens forma multiseries as determined by Bates et al. (1989) was between 1 and $6 \times 10^{-12} \mathrm{~g} \mathrm{cell}^{-1}$. The rate that we have determined for $N$. pseudodelicatissima was considerably lower: $7.0 \times 10^{-15}$ to $9.8 \times 10^{-14} \mathrm{~g}$ cell ${ }^{-1}$. However, the $N$. pseudodelicatissima cells are considerably smaller in size and volume. $N$. pseudodelicatissima are 55 to $80 \mu \mathrm{m}$ long and 1.5 to $2.0 \mu \mathrm{m}$ wide, whereas $N$. pungens forma multiseries are 80 to $140 \mu \mathrm{m}$ long and 4.5 to $6 \mu \mathrm{m}$ wide. Assuming cylindrical shape, $N$. pseudodelicatissima would be ca 18 times less in volume than $N$. pungens; hence toxin production is more comparable on a cytoplasmic basis, although still 3.5 times less than in the former species. This may also explain why, although Nitzschia numbers reached similar densities $\left(10^{6}\right.$ cells $\left.^{-1}\right)$ in both PEI and the Bay of Fundy, domoic acid levels in blue mussels from eastern PEI were in excess of $300 \mu \mathrm{g} \mathrm{g}^{-1}$, whereas at Stn 18 (Fig. 1) in Passamaquoddy Bay, the highest levels of domoic acid detected in blue mussels was $74 \mu \mathrm{g} \mathrm{g}^{-1}$ (Gilgan et al. 1990).

We conclude that the pennate diatom Nitzschia pseudodelicatissima was the major source of domoic acid occurring in shellfish and seawater in the southwestern Bay of Fundy during 1988. Since this diatom 
has been found throughout the world, it is essential to conduct more extensive studies in other localities. Domoic acid may be present in other regions of the world, whether it is produced by another algal species, fungus or bacteria. Until further studies of domoic acid production by axenic and non-axenic cultures are completed, many questions remain unanswered that need to be resolved to better understand the production and fate of domoic acid.

Acknowledgements. We thank M. Poulin and G. R. Hasle for confirmation of the identity of Nitzschia pseudodelicatissima; M. LeGresley and J. Power, for phytoplankton analyses; Capt. F. Guptill, M. Ringuette and A. J. Wilson, for collection of samples; $W$ McMullon and F. Cunningham, for graphic services; $B$. Best for typing the manuscript; $R$. Pocklington for confirmation of domoic acid.

\section{LITERATURE CITED}

Bates, S. S., Bird, C. J., de Freitas, A. S. W., Foxall, R., Gilgan, M., Hanic, L. A., Johnson, G. A., McCulloch, A. W., Odense, P., Pocklington, R., Quilliam, M. A., Sim, P. G., Smith, J. C., Subba Rao, D. V., Todd, E. C. D., Walter, J. A., Wright, J. L. C. (1989). Pennate diatom Nitzschia pungens as the primary source of domoic acid, a toxin in shellfish from eastern Prince Edward Island, Canada. Can. J. Fish Aquat. Sci. 46: 1203-1215

Daborn, G. R. (1986). Effects of tidal mixing on the plankton and benthos of estuarine regions of the Bay of Fundy. In Bowan, M. J., Ventsch, C. M., Peterson, W T (eds.) Lecture notes on coastal estuarine studies. Springer-Verlag, New York, p. 390-413

Gilgan, M. W., Burns, B. G., Landry, G. J. (1990). Distribution and magnitude of domoic acid contamination of shellfish in Atlantic Canada during 1988. In: Graneli, E., Anderson, D. M., Edler, L., Sunström, B. (eds.) Toxic marine phytoplankton. Elsevier, New York, N. Y., p. 469-474

Gran, H. H., Braarud, T (1934). A quantitative study of the phytoplankton in the Bay of Fundy and Gulf of Maine (including observations of hydrography, chemistry and turbidity). J. Biol. Bd Can. 1: 279-467

Guillard, R. L. (1984). Culture of phytoplankton for feeding marine invertebrates. In: Berg, C. J. (ed.) Culture of marine

This article was submitted to the editor invertebrates. Hutchinson Ross Publ. Co., Stioudsburg, $P A$, p. 108-132

Hasle, G. R. (1965). Nitzschia and Fragilariopsis species studied in the light and electron microscopes. II. The group Pseudonitzschia. Skr Utgitt. Norske Vidensk-Akad. I Oslo I. (Mat.-Naturv. Kl.) N.Y Ser. No. 18: 1-29

Lawrence, J. F., Charbonneau, C. F., Menard, C., Quilliam, M. A., Sim, P. G. (1989). Liquid chromatographic determination of domoic acid in shellfish products using the paralytic shellfish poison extraction procedure of the Association of Official Analytical Chemists. J. Chromat. 462: 349-356

Maranda, L., Wang, R., Masuda, K., Shimizu, Y (1990). Investigation of the source of domoic acid in mussels. In: Graneli, E., Anderson, D. M., Edler, L., Sunström, B. (eds.) Toxic marine phytoplankton. Elsevier, New York, p. 300-304

Martin, J. L., White, A. W. (1988). Distribution and abundance of the toxic dinoflagellate Gonyaulax excavata in the Bay of Fundy. Can. J. Fish. Aquat. Sci. 45: 1968-1975

Subba Rao, D. V (1988). Domoic acid - a neurotoxic amino acid produced by the marine diatom Nitzschia pungens in culture. Can. J. Fish. Aquat. Sci. 45: 2073-2079

Todd, E. C. D. (1990). Amnesic shellfish poisoning - a new seafood toxin syndrome. In: Graneli, E., Anderson, D. M., Edler, L., Sunström, B. (eds.) Toxic marine phytoplankton. Elsevier, New York, p. 504-508

Trites, R. W. Garrett, C. J. R. (1983). Physical oceanography of the Quoddy Region. In: Thomas, M. L. H. (ed.) Marine and coastal systems of the Quoddy Region, New Brunswick Can. Spec. Publs. Fish. aquat. Sci. 64: 1-306

Wildish, D. J., Martin, J. L., Wilson, A. J., DeCoste, A. M (1988). Environmental monitoring of the Bay of Fundy salmonid mariculture industry during 1986 and 1987. Can. Tech. Rep. Fish. Aquat. Sci. 1648: 1-44

Wildish, D. J., Martin, J. L., Wilson, A. J., Saulnier, A. M. (1990). Environmental monitoring of the Bay of Fundy salmonid mariculture industry during 1988 and 1989. Can. Tech. Rep. Fish. Aquat. Sci. (in press)

Wright, J. L. C., Boyd, R. K., de Freitas, A. S. W., Falk, M. Foxall, R. A., Jamieson, W. D., Laycock, M. V., McCulloch, A. W., Mclnnes, A. G., Odense, P., Pathak, V. P., Quilliam, M. A., Ragan, M. A., Sim, P. G., Thibault, P., Walter, J. A., Gilgan, M., Richard, D. J. A., Dewar, D. (1989). Identification of domoic acid, a neuroexcitatory amino acid, in toxic mussels from eastern Prince Edward Island. Can. J. Chem. 67: $481-490$

Manuscript first received: May 9, 1990

Revised version accepted: July 30,1990 